\title{
Promotion of World Heritage Values: Experiences in St. Petersburg and Other Cities of Russia
} Elena BELOKUROVA, Dmitry VOROBYEV

\begin{abstract}
The paper reflects the experiences of the social movements, civic initiatives and NGOs in St. Petersburg and other cities of Russia as well as in some other post-Soviet countries, aimed at the promotion and raising awareness of local populations about the World Heritage value in their cities. These efforts are needed, because the outstanding universal values of the historic centres of St. Petersburg and other cities are threatened by illegal construction, misguided urban planning, neglect and a lack of public attention; churches and cultural landscapes suffer from poor restoration, development pressure and an unregulated tourism boom. These effects are often possible because the almost most local population has no knowledge about the UNESCO World Heritage status and its implications. As a result, they are not sufficiently able to speak out for the protection of their site, and do not know how the status of world cultural heritage can help them. Moreover, the population has little understanding of both the cultural value for their own community and what it means to be a World Heritage in general, leading to an insufficient realization of the potentials in the status of world cultural heritage. In this paper, we try both to show our previous research results and academic materials on the topic, but also reflect on our experience of participation in different activities, and especially within the recent project implemented in 2017 and aimed on an intervention into the discursive and pragmatic space in the field of promotion and protection of St. Petersburg World Heritage site. However, to understand these experiences and reflections, it is necessary to present a historical context and conditions of the development of both the St. Petersburg World Heritage status and the St. Petersburg social movement for the protection of St. Petersburg world heritage.
\end{abstract}

Keywords: World Heritage, Community Involvement, St. Petersburg, Russia.

\section{Specifics of St. Petersburg World Heritage Site}

The reasons for the weak awareness of the people of St. Petersburg about its UNESCO World Heritage Site are connected with the history of its nomination. Thus, it was conducted in 1991, based on the previous lists prepared in the late 1980s. The first lists of the protected historic building and monuments of St. Petersburg appeared already in the $19^{\text {th }}$ century, which were later updated in the Soviet times after the World War II, which changed the situation very much, because many of them were destroyed or required substantial renovation. However, it was important for the nomination in 1991 that it took place as a result of the perestroika time (1987-1991), when the attention to the protection of histor- 
ical memory was one of the mist mobilizing topics for mass democratic movement in then Leningrad. As result of mass demonstrations protecting different monuments and historic buildings, the historic and cultural value was reflected in the public debates by becoming one of the most important requirements of a number of the democratic parties and leaders of St. Petersburg. Therefore, after their coming to power during the first free and fair elections, the protection of the historic and cultural value was strengthened in the local and national legislation. For these purposes, the new lists of protected monuments and buildings were created by the local experts and their archival studies conducted with the support of the new legislative and executive authorities of Leningrad (before 1991) - St. Petersburg (after 1991). Moreover, on the wave of opening to the world of the Soviet Union, in general, and of Russia, in particular, Leningrad was invited and had an opportunity to nominate the city as a World Heritage Site. This history is very good documented in the published memories of the nomination co-authors (see, for example, Nikolaschenko 2008).

This context of the late 1980s is very important for understanding the specifics of St. Petersburg nomination. On the one hand, it was very important for St. Petersburg experts, activists, the broader public and new democratically elected leaders to protect the historic heritage. On the other hand, the local efforts to protect the historic values were very much welcomed by the world community, that was in general very enthusiastic about the end of the Cold War and the political and social opening of the Soviet Union. As a result, the nomination was unique: the activists and experts included into the nomination as many different objects and components as possible, at the same time having no elaborated materials and argumentation about the inclusion of many of them. The WHC has supported the nomination with big enthusiasm and approved the nomination without any additional requirements.

As a consequence, Leningrad and later, St. Petersburg, a is a unique case of the World Heritage Sites in comparison with the other world heritage cities, which includes not only historic centre, but also peripheral historic and natural landscapes and objects as well as some elements in the suburbs. The centre of historic St. Petersburg is only one of 36 components of the nomination "Historic Centre of Saint Petersburg and Related Groups of Monuments" (UNESCO $2018)^{1}$. In the nomination text, the outstanding universal value of the Site includes ensembles, perspectives and views, separate historic monuments (three centuries of construction), but also history, place and nature, architecture, industry, fortification, underwater and even underground heritage.

\footnotetext{
${ }^{1}$ More information available in KGIOP 2018.
} 


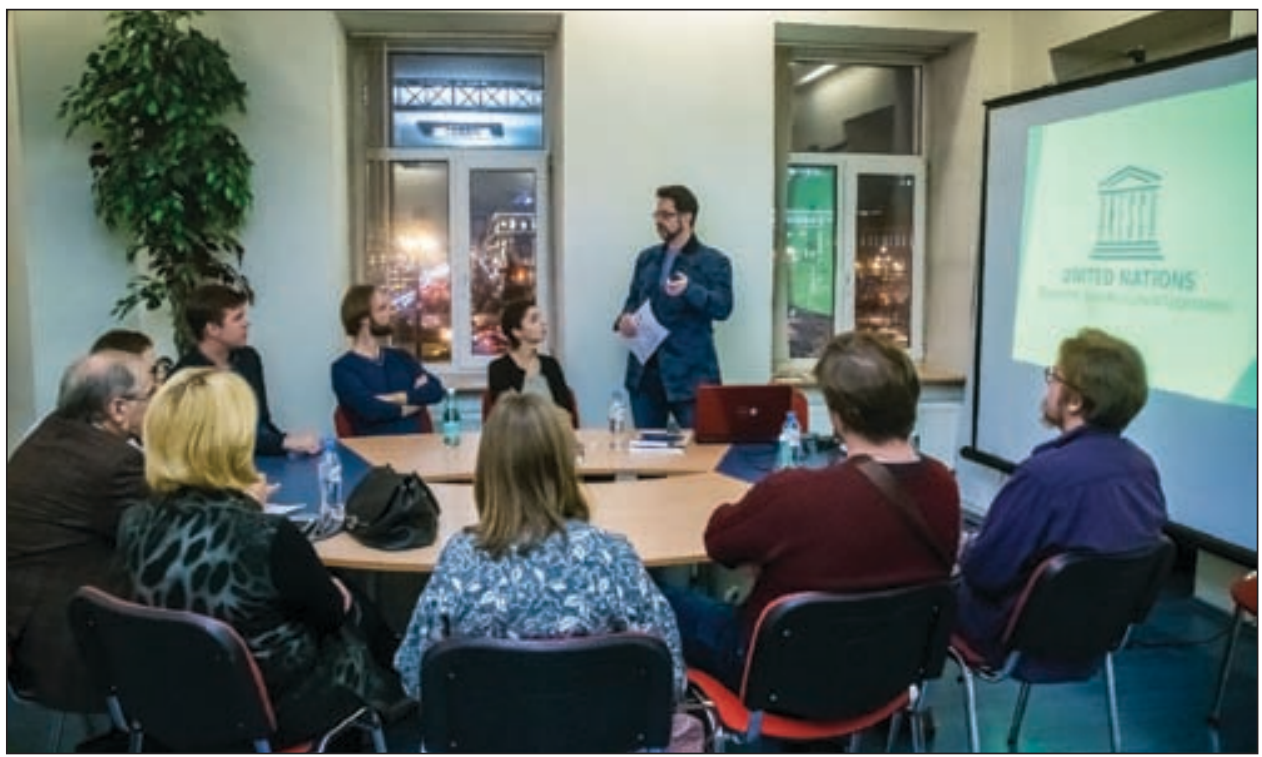

Figure 1. St. Petersburg Seminar with the tourist industry and guides, November 24th, 2017

The detailed research and description of all the components of the nomination was conducted only later and presented in the form of a small re-nomination in 2005 and later in 2009-2010. In that moment, there was an attempt to reformulate the components, to make them in a more logical and structural way, but it was unsuccessful and not accepted by the WHC. However, the more precise description and borders and the descriptions of the components were adopted that until now stay the essence of WHS, in spite of the further permanent work on the understanding of the values of all of them.

Therefore, the current official description of all the components contains about 1000 pages, and it is not known to the broader public and even to the most activists. At the same time, the general topic of the architectural heritage protection and the World Heritage Site is very popular among social movements and in public debates in St. Petersburg public sphere. This is another factor for understating the situation of the world heritage promotion, and this will be explained in the next chapter.

\section{Specifics of the City Protection Movements and Activism in St. Petersburg}

Although the whole responsibility for the nomination and protection of a World Heritage Site is in the hands of a Convention state party, i.e. special national authority, contacting the World Heritage Centre and receiving the inspections, questions and requirements of the UNESCO institutions, in 
St. Petersburg this function is fulfilled by the Committee for the Historical and Cultural Monuments Protection.

However, in order to understand its work for the World Heritage protection and values promotion, it is necessary to take into account social movements and city protection community as well, which is very strong in St. Petersburg, both in the public debates and politics ${ }^{2}$.

Thus, a very important role is still played by St. Petersburg Branch of the VOOPiK formally, All-Russian Union of the Protection of Historic and Cultural Monuments, one of the Soviet organizations, which was kept along with the VOOP (All-Russian Society of Nature Protection) and some other all-Russian huge member organizations. In spite of very significant political changes, these organizations have kept their structure and have their branches at almost all of the regional and local levels, keeping their autonomy in definition of their objectives and conducting their activities in different regions. In St. Petersburg, it is very active and includes a lot of activists engaging for the monuments protection.

Moreover, a lot of activists are not included into some NGOs, but are actively involved into the social movements and informal networks. The social movements in the late 1980s were already mentioned as having one of their focuses in St. Petersburg on the heritage protection. Some of these activists became later experts or politicians.

The second wave of the social movements for the so-called "city protection" (gradozaschita) was strengthened in the 2000s as a response to the intensification of the new construction instead of parks and empty places within the city centre, and since 2005 to the mass demolishing of the historic city centre as well. The movement was strengthened especially in 2007-2009, when it was culminated in the struggle against 450-meter high Gazprom Tower, which was planned to be built in the city centre. The grass-roots movements have managed to protect the city centre and to convince the city administration to replace the construction to the city edge. At the same time, during this time, a lot of other development projects were normalized. Paradoxical actions and satire together with the analytics and expert work with media and administration led to many successes of the movement in a very difficult situation of the active re-construction of St. Petersburg city administration. Here, the repertoire of the local social movements, such as the most known Living City network and other initiatives was aimed mostly on the protests against some development and new construction projects.

2 See more information at Cicil and Minhenok 2013. Very detail descriptions of St. Petersburg's WHC components presented in Gorbatenko 2011. List of threats to St. Petersburg's WHC components presented in Gorbatenko 2018. 
At the same time, during the struggle against Gazprom Tower, appeals to the UNESCO rules became very important, and the activists met some inspections and representatives sent to the city by different UNESCO institutions. Therefore, when in 2012, the annual World Heritage Committee session took place in St. Petersburg, the city activists initiated an NGO and activists Conference before the official WHC session. During this conference, St. Petersburg activists argued against this construction, and civil society representatives from different countries could also report about their problems. Due to the Conference, the World Heritage Watch (WHW) was initiated, which was registered in 2014 in Berlin and is also now very actively working as international NGOs and activists network. This allowed St. Petersburg activists and experts to make the fact about the St. Petersburg status as World Heritage Site visible in the media and public space. However, at the same time, in spite of the active involvement of many St. Petersburg people into the heritage protection, the WHC session in St. Petersburg stated for many of them quite not known and visible.

To sum up, in the field of the heritage protection in St. Petersburg, beside the city authorities, there are a lot of social movements and initiatives, that have a long history of using different methods, among them the most popular were protests, direct actions, media campaigns, legal protection, lobbyism, etc. Sometimes they also organized exhibitions, public lectures, excursions and discussions in order to promote the heritage values among the broader public, but they were not the most widespread practice and were not oriented on the world heritage idea. The promotion of values was in general very weak, and only now it comes as an objective of the work. Moreover, in spite of the very intensive public debates about the heritage protection, the UNESCO World Heritage Status was not so important for them (with an exception of the Gazprom Tower case), and the understanding of its essence among activists is quite low.

This activity of the heritage values promotion is usually implemented by other different initiatives and organizations involved into the heritage protection, such as educational and cultural institutions. In their work, they prefer quite boring, old and traditional methods of work, mostly with children and young people. In their work, they pay some attention to the World Heritage Status of St. Petersburg, but it is just a fact, mentioned during the lessons and events.

Therefore, nowadays for the civil society organizations and initiatives, which deal with the protection of cultural heritage, it is very topical not only to organize pressure on the governments and businesses, but also to promote shared values of world heritage sites and to improve understanding of the UNESCO World Heritage Convention among the broader public. Moreover, 


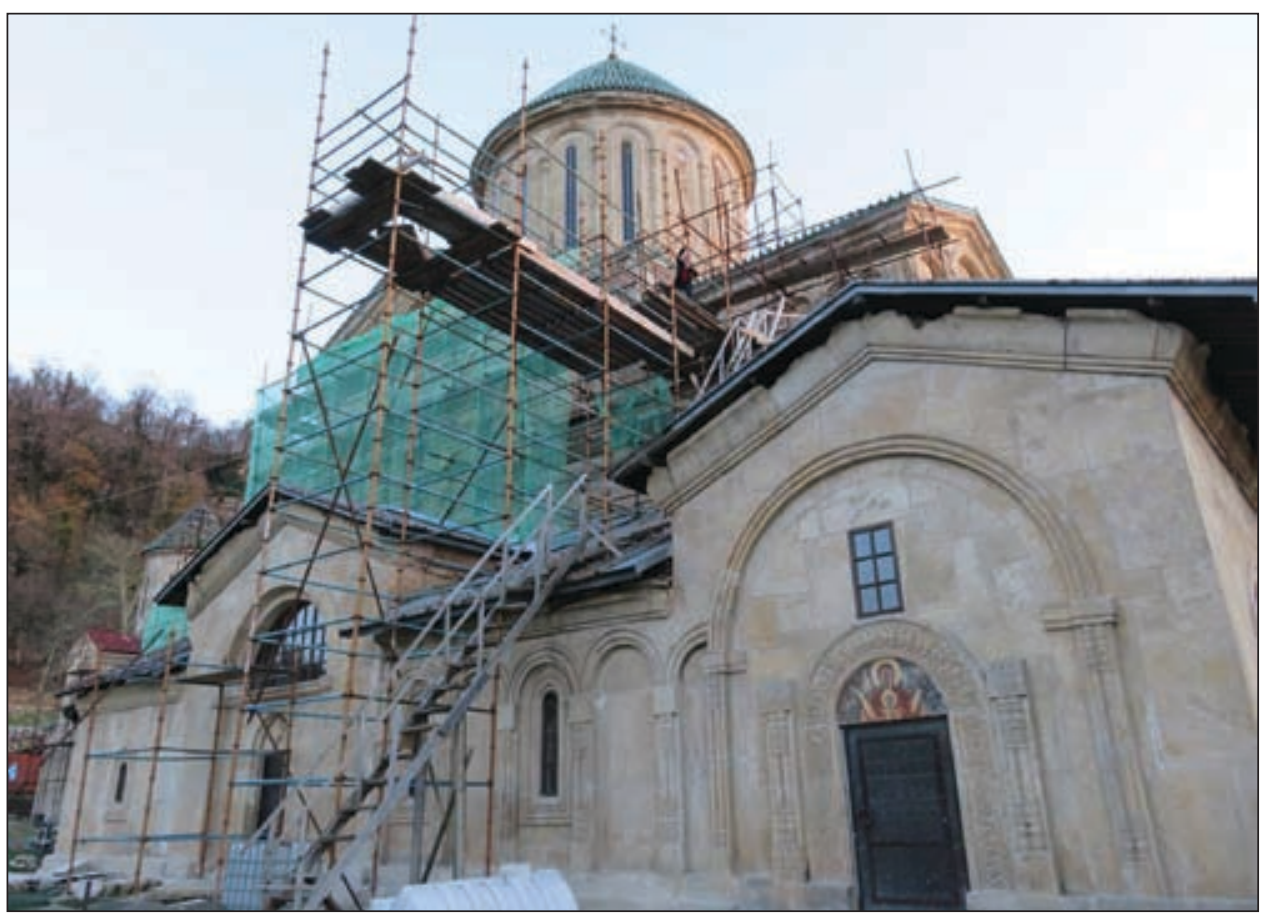

Figure 2. Pskov Seminar, December 8th, 2017

it is necessary to do it in the innovative and creative way, in order to make this topic interesting and attractive not only for children, but also for adults, not only for the activists, but also for the regular people.

\section{Practical Experiences in World Heritage Protection}

With such a task and in such a context we approached our project "Strengthening Common Engagement and Mutual Support in Raising Awareness of World Cultural Heritage Values" implemented in 2017 within the World Heritage Watch network with support of the German Foreign Ministry. Aside of us, the activists and NGOs from Germany, Ukraine, Georgia and Armenia participated in this international project, but in this paper, we mostly reflect on the implementation of the project in St. Petersburg and some other cities of Russia.

Thus, the initial idea was to reflect, understand the needs and make some intervention into the heritage protection community of St. Petersburg and other Russian cities in order to find some new ways and opportunities for the promotion of the world heritage values. To do so, we defined the following methods and ways of the value promotion as relevant:

- Collection, production and dissemination of audiovisual materials about the World Heritage sites both on-line and off-line; 
- Seminars about the regime of the World Heritage Convention which governs the sites for multipliers, with such target groups as activists, tour guides, teachers, youth groups and journalists working on heritage;

- Consultation Meetings with other NGOs and experts working in other fields such as climate change, nature conservation, urban planning, sustainable development, human rights, good governance, business, construction and development etc. for understanding common interests and implementation of common actions;

- International cooperation within the World Heritage Watch, networking and exchange for the promotion of world heritage values in different countries and sites.

In the framework of the project, we applied all these methods, and the results were quite surprising and important for the reflection about the current and desirable situations in the field of the word heritage promotion.

Firstly, it became clear that the information about the World Heritage Site is really unknown not only to the broad public in St. Petersburg, but also to the activists and possible multipliers. Therefore, the search and production of materials, which would be understandable and accessible for the different audiences became one of the central tasks. Therefore, the following was done in this field:

- Preparation of the digest from the materials of Description of Outstanding Universal Values: here, more and more new materials, facts and studies were found, which are practically not known to the public.

- Analysis of the nomination and re-nomination history and materials, maps and other materials produced by the St. Petersburg city administration for the UNESCO institutions, especially from the years 2009-2010;

- Discourse analysis of the arguments pro and contra St. Petersburg as World Heritage Site, main actors and public perception, including especially the dichotomy «the city should develop vs historic city».

During this work, it became clear, how important and topical was an initiative from some local St. Petersburg restauration and development companies that wanted to demonstrate their interest in promotion of the heritage values and proposed already in 2016 to include into one of their reconstruction projects something like World Heritage Information Centre. The possible creation of such an Info Centre would provide a space for permanent exposition and temporary exhibitions, as well as opportunities for organization of different events for different target groups. Therefore, in the framework of the project we also started to collect materials for the future exposition, such as historic materials about the nomination of St. Petersburg as World Heritage Site, interviews 


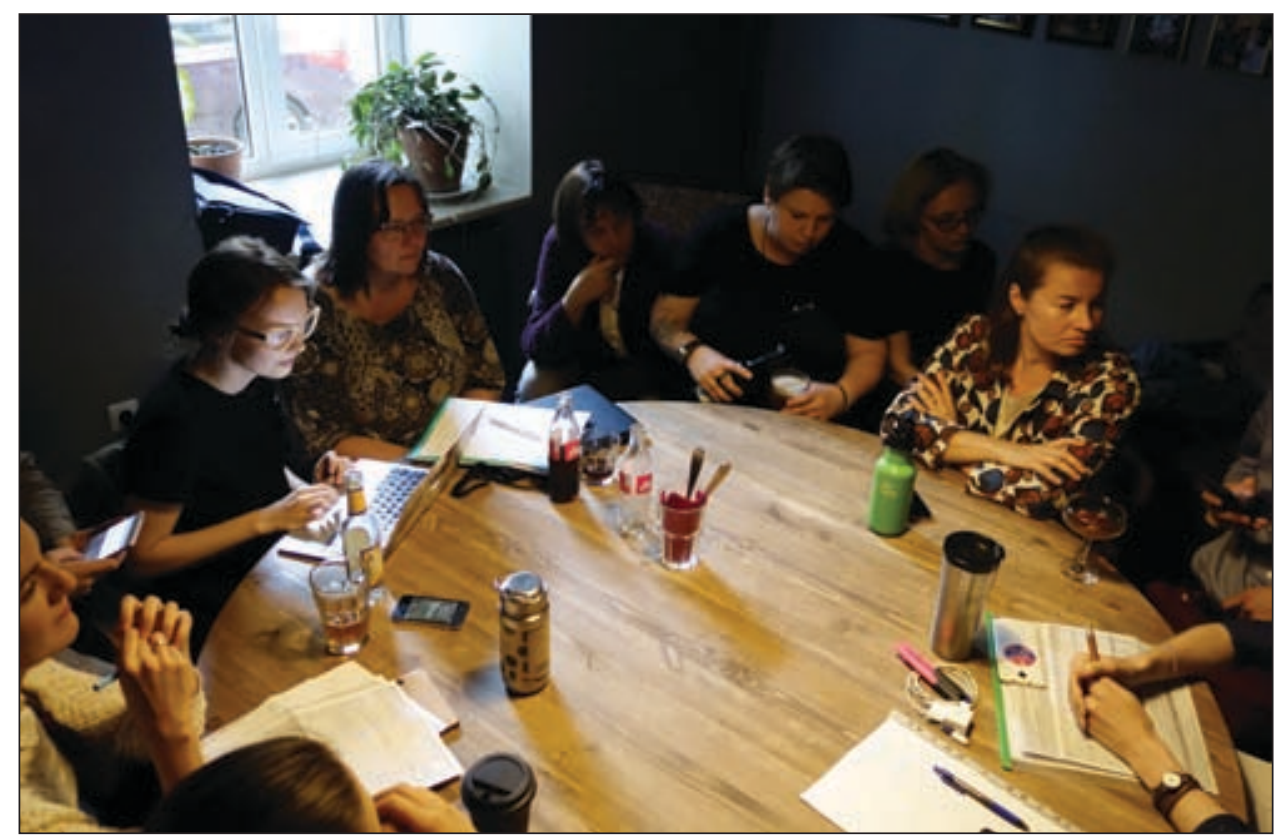

Figure 3. St. Petersburg Seminar on the tourist industry, November 24th, 2017

(video) and their analysis with the co-authors of the nomination and experts, in order to make them later a basis for the multi-media exposition in the future World Heritage Info Centre.

Unfortunately, the project proposed earlier was not implemented because of another decision taken by the city administration regarding the building, where it was initially planned. But the idea is still alive and hopefully will be implemented in another historic building in the centre of St. Petersburg. So, the task of collection and presentation of materials is still very important.

\section{Seminars and Discussions}

\section{with Local Multipliers of the Values Promotion}

Aside the collection and production of materials, we planned to organize seminars and discussions with different multipliers and potential partners within the project in order to give them input about the World Heritage issues, and at the same time to get their feedback about their perceptions and further needs. Moreover, the seminars and consultations were organized not only in St. Petersburg, but also in nearly situated Petrozavodsk and Pskov, interested in this topic in different ways depending on their own situations. The seminars brought us a unique and interesting experience, which we also would like to share. 


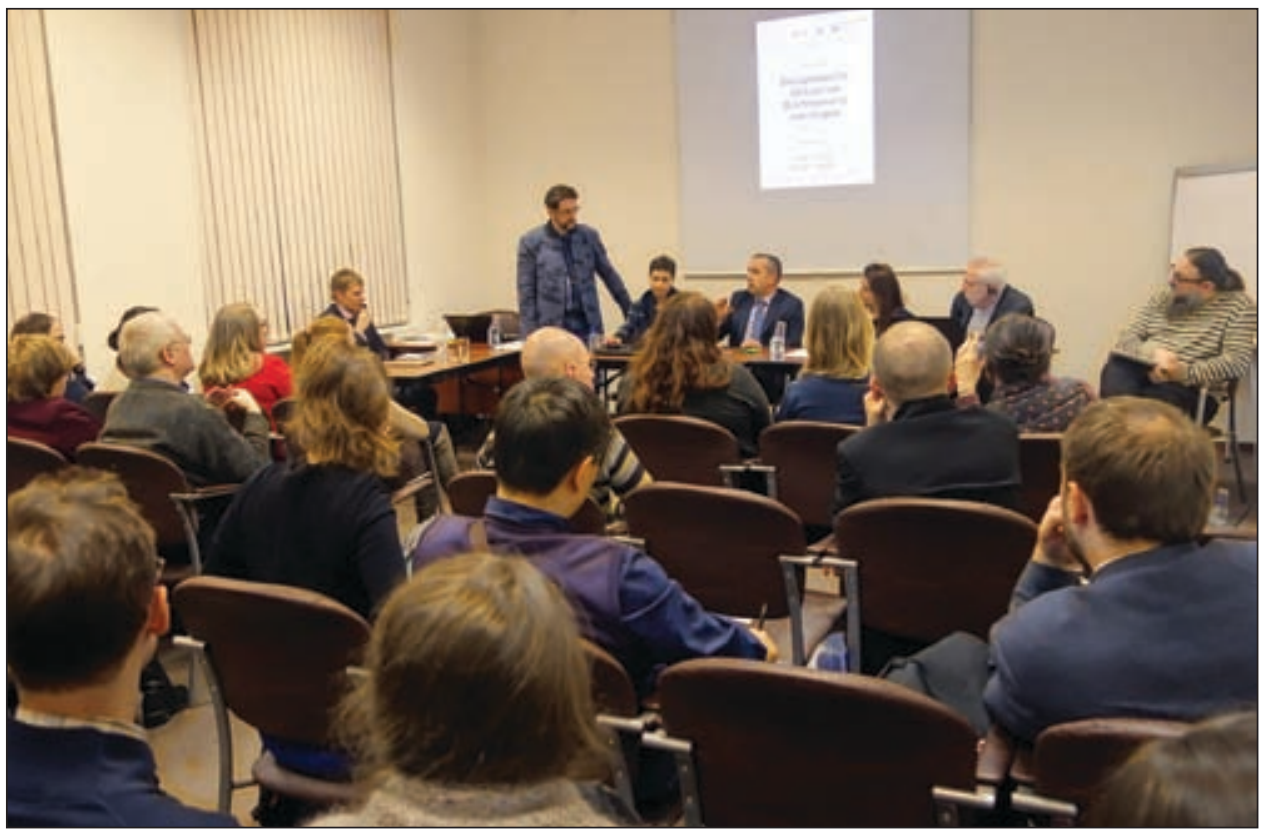

Figure 4. Public Discussion in St. Petersburg, December 2nd, 2017

\section{St. Petersburg Seminar with}

the tourist industry and guides, November $24^{\text {th }}, 2017$

It was the first seminar with a group of guides and experts in the local history and culture, which was aimed not only on the transfer of knowledge, but also on the discussion and feedback from them. Firstly, the members of our team gave three short lectures on the history of St. Petersburg nomination as a World Heritage Site, about the actual challenges and international civic and expert initiatives for protection of the World Heritage sites. Our presentations and handouts aroused a great interest among the participants of the round table. Almost all participants, regardless of their experience, found out something new about the elements and components of the nomination in St. Petersburg. For instance, it was discovered that many of them thought up until this point that only the historical centre of the city had the World Heritage status. Especially surprising for the participants was the fact that also other Site elements, such as the thoroughfares of the city, the Neva River, the fairways in the Gulf of Finland, and also historic areas in the city suburbs and even villages are also components of the World Heritage Site.

This experience confirmed that we had been using the right strategy: organize information and discussion groups and keep adapting the materials on World Heritage sites according to the working method applied by UNESCO 
institutions. A the same time, we also noticed that the title of the Seminar was not so attractive and quite boring: just mentioning the topic of UNESCO is not enough and it looks quite boring, people are sure they know everything about it, even if they don't know so much. In total, not so many people came for the Seminar, and mostly those, with whom we spoke personally in advance by explaining the context and the advantages of the Seminar. Therefore, we decided to think more on the more attractive titles and provocative questions for the further discussions in St. Petersburg.

Aside of St. Petersburg, we organized two further seminars in other cities and with other target groups, which actually demonstrated their own specifics.

\section{Petrozavodsk Seminar on Kizhi, November 29 ${ }^{\text {th }}, 2017$}

Petrozavodsk city is not so far away from St. Petersburg, in the Russian North, where another World Heritage Site is situated on the Kizhi Island, due to its landscape and cultural importance. Amid its natural attractions, there are masterpieces of wooden architecture, such as the museum-reserve.

The preparation of the Seminar in Petrozavodsk consisted of the search of the local partners and participants, as well as preparation of the local programme. Although it was the first Seminar with the local partner - National Park - it was very successful. Our initiative, organizational and financial resources made it possible for the participants of the seminar to meet and discuss professional issues, which is a quite rare opportunity for provincial cities. On the initiative of the same local experts, the meeting was held in the format of an intensive conference with short thematic presentations by almost every participant. It should be noted that there were more than 30 participants, as in our following events.

\section{Pskov Seminar, December $8^{\text {th }}, 2017$}

For this seminar we used the contacts that we had been making up until the moment and tried to find out, as far as possible, the needs of the local community. The community was interested in the protection and promotion of the historical heritage of the city. For twenty years, Pskov has been trying to be nominated as a World Heritage Site and at the moment it is very close to it. On the basis of the talks with the main stakeholders of the city, we realized that the principal need was for recognized experts, who could explain in a simple way the situation of the nomination of historical cities as a whole, as well as the impact of adopting this status. Our task was to find such an expert in St. Petersburg and bring him/her to Pskov, and we accomplished it successfully indeed. A great surprise was that after his remarkable and extremely informative lecture, the representative of the city administration, which is directly engaged in the nomination of Pskov as a World Heritage site, decided to come to the po- 


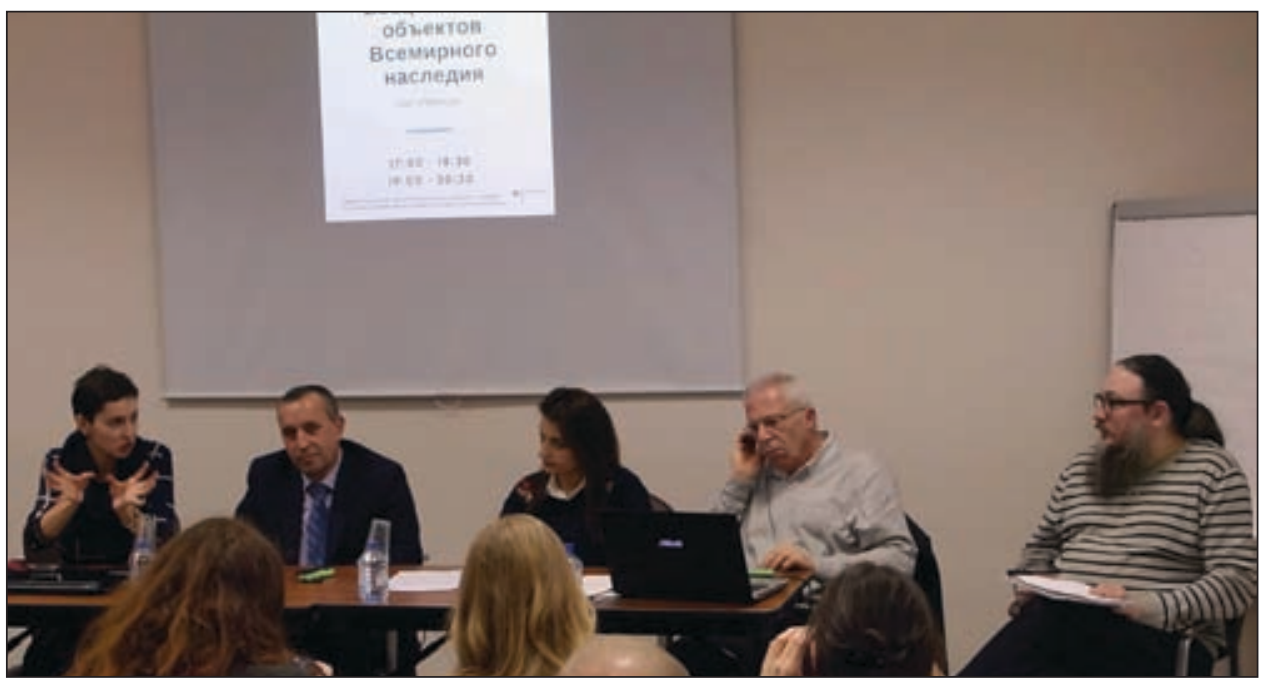

Figure 5. Public Discussion in St. Petersburg, December 2nd, 2017

dium and make a presentation. This was almost the first time when functionaries had been able to talk to the public about the efforts they were making and answer relevant questions from the audience.

\section{Public Discussion in St. Petersburg, December $2^{\text {nd }}, 2017$}

We planned this crucial event to be as open as possible and involve into the discussion as many as possible local people in St. Petersburg. However, by having already an experience, when the local experts found the topic of St. Petersburg as World Heritage Site quite boring, we stated the question: how to invite experts and public to such a topic? Our previous experience had shown that in St. Petersburg there is a quite small and isolated community of professionals like officials, local experts and civil activists who have information about the real developing situation in St. Petersburg around its World Heritage status. In fact, it is a couple of experts in a multimillion city. An obstacle to enter this experts' community is, first of all, the extremely formalized language used in the description of the sites' relevance, its elements and components, as well as the problem of multilingualism (not all the documents are available in French, English and Russian). Furthermore, the secrecy of many documents and working meetings has led to the fact that, despite the fact that there is a detailed description of the nomination and there is a high demand on this information, it is practically not available to non-professionals.

Therefore, we decided to go for the brass ring and hold an open debate with a provocative and, in some circles, taboo-like question as "Does St. Petersburg Need to Keep the World Heritage Status?" There is no doubt that such a con- 
trolled provocation worked well and the announcement of the Public Discussion was spread among city protection nets. This initiative even forced St Petersburg branch of ICOMOS to issue a press release, whose main idea was that such formulations were inadmissible and that there is no doubt that St. Petersburg must preserve its World Heritage Site status.

The contrived dramatic of the Public Discussion due both to the title and to the invitation of some representatives of the city administration and development business was perceived by the participants of the meeting as a provocation, as a show with a certain informative magic and stand up elements, but not as a classic podium discussion. We looked for this format, which enables to "de-spell" the knowingly boring, incredibly difficult and unintelligible subject of the preservation of the World Heritage, and we believe we have succeeded.

This led to a very productive discussion, through which not only the history and the specifics of St. Petersburg nomination were discussed, but also the approaches to the significance of a World Heritage status. Thus, it became obvious through the debate that there is a dichotomy in these approaches. Some people traditionally see St. Petersburg heritage as part of the Russian history and culture, which was so much accepted by the world community as unique that it was invited to be a member of the "world club" of other World Heritage Sties. The most local people are proud of it and, therefore, should protect it. However, during the discussion, another possible approach was likewise formulated, and namely that St. Petersburg is among other World Heritage sites as it presents one peach of the world history and culture, and, therefore, has, beyond Russian, the global value and significance. In the discussion it became clear that this element is missing in the regular protection: St. Petersburg's value is presented as Russian and local value, but not as global value and as one of the many other pieces of the global value, which together constitute the World Heritage as such.

This thesis changes the concept of the city protection by bringing it from the local to the global level. This dichotomy of the Site as «part of the World Heritage to be protected for the World» vs. «our great uniqueness, which was recognized by the World» underlines the fact who possesses the Site: all the people of the world or St. Petersburg/Russian inhabitants? Who bears the responsibility over it? This discussion was extremely important (see part of the video in Doempke 2017) and should be continued, because it has very important consequences for the understanding and further promotion of the World Heritage values.

In general, the consultations and seminars with multiplayers have demonstrated the lack of knowledge and understanding of the World Heritage 
regime, in general, and St. Petersburg's status and its specifics, in particular. Moreover, it became clear that different target groups have different focuses and interests. Thus, the tour business is interested in getting new ideas for more attractive presentation of the city history, sights and current city life. The school teachers are interested in more lively and children-friendly presentations of the local history and needs for the world heritage protection. The local community, business and administration are interested in more sustainable development of the city and urban structure, which requires more sustainable understanding of the world heritage values in the community in general.

For the future work on the World Heritage values promotion it means that each target group needs its own format of the information presentation, by taking into account their lack of knowledge. Moreover, the project showed that the collection and dissemination of materials are important, but they are difficult tasks, because the people are overwhelmed by the information in general, and only very interesting and up-to-dated pieces of information can be asked by the people. Moreover, it should be presented in very modern ways by using the latest technological achievements. Therefore, the search for innovative methods of presentation and promotion of values for different target groups within the local community is needed and worth for the international and interregional exchange.

\section{Conclusions}

By taking into account the specifics of St. Petersburg as World Heritage Site connected with the historical conditions of its nomination in 1991 and very important role played by the activist community and social movements in the heritage protection, the most relevant and effective practices for the further work on the world heritage values protection are the following:

- Further collection, analysis and adaptation of the nomination materials and relevant documents and narratives for the popularization among the broader public;

- Awareness-raising through well-prepared public events for different target groups of multipliers, by taking into account their needs and interests, including different (also peripheral) components of the World Heritage Site;

- Long-term informational projects would be more effective rather than separate info-events;

- Involvements of local communities into the world heritage values promotion, for example by creation of permanent working groups of tour guides, teachers, representatives of cultural institutions etc. for the exchange of in- 
formation and visions on the values promotion, creation of popularization materials, discussion of new ideas, consolidation of local community;

- Creation of new presentation forms for the popular values promotion, such as, for example, playing cards, games, innovative and interactive guided tours, quests, interactive maps etc. for different target groups, wiki on the basis of these materials.

By reflecting the results of our interventions, it is also necessary to mention some problems, such as the following: lack of time and finances for the whole work on the values promotion; danger with the foreign funding, which is specifically important for Russia and maybe some other countries; difficult understanding of local needs, because it is often not public and not clear, insufficient international exchange.

Some solutions for all the above-mentioned problems can be discussed during the Conference, especially what concerns the international cooperation. Among the ideas that our groups have been trying to propose for many years, is to possibly organise the competition and exhibition of pictures in different WH sites (beauty and problems) across the world. Such an exhibition would promote not only the ideas of separate Sites, but in general would show the significance of the World Heritage values as a whole.

\section{References}

Cicil, C. and Minhenok, E., eds. St Petersburg: Heritage at Risk. Maps: Moscow St. Petersburg, 2013.

Doempke, S. (2017). Public talk on discussion "Priceless World Heritage". Online: youtube.com/watch?v=4pB-70o8qDM.

Gorbatenko, S. (ed.) (2011). World Heritage - The Historical Landscape of the Saint Petersburg Agglomeration. ICOMOS St. Petersburg National Branch.

Gorbatenko, S. (ed.) (2018). Situation of danger to the World Heritage site "Historic Centre of Saint Petersburg and Related Groups of Monuments". ICOMOS St. Petersburg National Branch.

KGIOP (2018) = St. Petersburg Government. Committee for the state preservation of historical and cultural monuments. Saint Petersburg and World Heritage. Online: kgiop.gov.spb.ru/en/st-petersburg.

Nikolaschenko, B. (2008). Seven Wonders of the World, the Birth of Ideas and the World Heritage Concept. Bulletin of the Research Center of the General Plan 3.

UNESCO (2018) = UNESCO World Heritage Centre. Historic Centre of Saint Petersburg and Related Groups of Monuments. UNESCO. Online: whc.unesco.org/en/ list $/ 540$. 


\section{Promovarea patrimoniului mondial: experiențe din Sankt Petersburg și alte orașe din Rusia}

\section{Rezumat}

Articolul reflectă experiențele mișcărilor sociale, inițiativelor civice şi ale ONG-urilor din Sankt Petersburg și din alte orașe din Rusia, precum și din alte țări post-sovietice, destinate promovării și sensibilizării populațiilor locale cu privire la valoarea patrimoniului mondial în orașele lor. Aceste eforturi sunt necesare deoarece valorile universale remarcabile ale centrelor istorice din Sankt Petersburg și ale altor orașe sunt amenințate de construcții ilegale, planificare urbană greșită, neglijare și lipsă de atenție publică; bisericile și peisajele culturale suferă de restaurări deficitare, presiune dictată de interese economice de moment și un boom turistic nereglementat. Efectele nocive se produc adesea și pentru că practic majoritatea populației locale $\mathrm{nu}$ are cunoștințe despre statutul de patrimoniu mondial UNESCO ale siturilor şi implicaţiile sale. Drept urmare, ea nu este suficient de capabilă să se pronunțe pentru protecția siturilor lor și nu știe în ce fel o poate ajuta statutul patrimoniului cultural mondial. Mai mult, populația nu înțelege nici valoarea culturală pentru propria comunitate, nici importanța mondială a patrimoniului, ceea ce duce la o realizare insuficientă a prevederilor din statutul patrimoniului cultural mondial. În această lucrare, încercăm să arătăm atât rezultatele cercetărilor noastre anterioare, cât și materialele academice pe această temă, dar reflectăm și asupra experienței noastre de participare la diferite activităţi, mai ales în cadrul recentului proiect implementat în 2017, ce reprezintă o intervenție discursivă, dar și una pragmatică în favoarea promovării și protecției sitului Patrimoniului Mondial Sankt Petersburg. Totuși, pentru o mai bună înțelegere a acestor experiențe și reflecții, este necesar să prezentăm un context istoric şi condițiile dezvoltării atât a statutului de Patrimoniu Mondial din Sankt Petersburg, cât și a mișcării sociale din Sankt Petersburg pentru protecția patrimoniului mondial din Sankt Petersburg.

Cuvinte cheie: patrimoniul mondial, implicarea comunităţii, Sankt Petersburg, Rusia.

Elena Belokurova, Russian group within the World Heritage Watch, St. Petersburg, Russia, E-mail: elena.v.belokurova@gmail.com Dmitry Vorobyev, Russian group within the World Heritage Watch, St. Petersburg, Russia, E-mail: moxabat@gmail.com 